\title{
ANALISIS AUDIT OPERASIONAL DALAM MENINGKATKAN EFEKTIFITAS BIAYA OPERASI PADA PT. PLN WILAYAH SULSELBAR
}

\author{
Muhaimin1 Amran2 Desi Kumala Sari3 \\ 1,2, 3 Universitas Muhammadiyah Makassar \\ e-mail:1d3pajak@unismuh.ac.id,2imsanmuha@gmail.com
}

\begin{abstract}
Research aims to determine the role of operational audits can increase the effectiveness of operation cost control in Makassar city. The research method used is a qualitative descriptive analysis research method. The data collection techniques used are Library Research and field research that is by conducting interviews to operational audits. The results of research using qualitative descriptive analysis suggest that the operational audit has a role in increasing the effectiveness of operating cost control. Based on the results of research and discussion that has been done can be concluded as follows: (1) Implementation of operational audit in PT PLN (Persero) Sulselrabar region always maintains its identification where operational auditors are given The freedom to complete its responsibilities honestly and to carry out its ability to audit.
\end{abstract}

Keywords: operational Audit, costs, operating

\begin{abstract}
Abstrak
Penelitian ini bertujuan untuk mengetahui peranan audit operasional dapat meningkatkan efektifitas pengendalian biaya operasi pada PT PLN (Persero) Kota Makassar. Metode penelitian yang digunakan adalah metode penelitian analisis deskriptif kualitatif. Teknik pengumpulan data yang digunakan adalah penelitian kepustakaan (Library Research) dan penelitian lapangan (Field Research) yaitu dengan melakukan wawancara kepada audit operasional. Hasil penelitian dengan menggunakan analisis deskriptif kualitatif menunjukkan bahwa audit operasional memiliki peranan dalam meningkatkan efektivitas pengendalian biaya operasi. Berdasarkan hasil penelitian dan pembahasan yang telah dilakukan dapat disimpulkan sebagai berikut: (1) Pelaksanaan audit operasional di PT PLN (Persero) Wilayah Sulselbar selalu mempertahankan indenpendensinya dimana auditor operasional diberi keleluasaan menyelesaikan tanggung jawabnya dengan jujur dan melaksanakan segala kemampuannya dalam mengaudit dan tetap mempertahankan sikap ojektifnya serta tercermin dari kedudukan unit audit yang terpisah dari bagian-bagian lain yang diperiksanya.
\end{abstract}

Kata Kunci: Audit Operasional, Biaya, Operasi 


\section{PENDAhuluan}

Sejalan dengan berkembangnya semakin banyak masalah yang timbul di dalam suatu perusahaan, salah satunya dalam menghadapi situasi bisnis yang semakin kompetitif. Agar tetap bisa berjalan, setiap perusahaan dituntut untuk memenuhi permintaan pasar dengan harga produk yang kompetitif. serta dengan kualitas dan mutu pelayanan yang optimal. Agar dapat tercapai setiap pemimpin perusahaanlah yang harus bisa mengoptimalkan segala sumber daya yang ada. Kemampuan perusahaan untuk memberikan pelayanan yang bermutu tinggi dengan harga yang kompetitif sangat dipengaruhi oleh kemampuan perusahaan tersebut untuk mengendalikan operasi perusahaan. Hal ini sangat penting untuk mengantisipasi munculnya pesaing. Kenyataan membuktikan, perusahaan yang mampu mengendalikan opersi perusahaan secara efektif dan efisien dengan tidak mengabaikan mutu pelayanan kepada konsumen akan mampu persaingan yang semakin berat.

Salah satu cara manajemen untuk dapat mengendalikan perusahaan secara lebih baik yaitu dengan mengendalikan biaya operasi sefisien dan seefektif mungkin agar biaya operasional tersebut tepat sasaran, ini juga bertujuan untuk menjaga agar tidak terjadinya penyalahgunaan biaya operasional yang akan merugikan perusahaan.dengan itu sebuah manajemen perusahaan perlu mengadakan audit operasional berkala. Melalui audit operasional, manajemen perusahaan dapat mengetahui pelaksanaan kegiatan operasi, masalah yang ada dalam kegiatan dan juga cara-cara untuk mengatasi masalah tersebut. Dengan demikin auditor dapat membrikan informasi yang diperlukan dalam membantu para pengelola perusahaan dalam proses pengambilan keputusan agar tujuan perusahaan tercapai dengan baik.

Pemilihan kegiatan operasi dengan alasan bahwa kegiatan operasi merupakan kegiatan merupakan kegiatan yang sangat dominan dan sangat berperan dalam memberikan pelayanan terhadap konsumen serta dalam kegiatan operasi membtutuhkan biaya untuk mendukung kegiatan tersebut yang meliputi, sarana dan prasaranapeningkatan sumber daya manusia, maka perlu ditangani serius untuk mencegah penyalahgunaan biaya. Penggunaan biaya operasi yang efisien tidak dapat terjadi dengan sendirinyanamun diperlukan adanya suatu perencanaan dan pengendalian yang memadai dalam penggunaannya.

Adanya suatu pengendalian yang memadai akan sangat membantu manajemen dalam melakukan pengendalian atas seluruh aktifitas yang ada di dalam perusahaan, termasukuntuk menilai tingkat efisiensi dan efektifitas biaya operasi perusahaan. Dengan audit operasional dapat mengetahui suatu proses yang sistematis untuk menilai efektifitas operasi dibawah pengendalian internal dan melaporkan kepada pihak manajemen dengan rekomendasi untuk perbaikan. Berdasarkan uraian dari latar belakang diatas maka permasalahan yang dibahas dalam penelitian ini adalah Apakah peranan audit operasional dapat meningkatkan efektifitas pengendalian biaya operasi pada PT. PLN (Persero) Kota Makassar?

\section{TINJUAN PUSTAKA}

\section{Auditing}

Sukrisno Agoes (2004) dalam bukunya Auditing (Pemeriksaan Akuntan) oleh Kantor Akuntan Publik mendefinisikan auditing sebagai suatu pemeriksaan yang dilakukan secara kritis dan sistematis oleh pihak yang independen terhadap laporan keuangan yang telah disusun oleh manajemen, beserta catatancatatan pembukuan bukti-bukti pendukungnya, dengan tujuan untuk dapat memberikan pendapat mengenai kewajaran laporan keuangan. Adapun jenis audit dibedakan ke dalam tiga jenis Audit atas Laporan Keuangan (Financial Statement Audit), Audit Kepatuhan (Compliance Audit) Dan Audit Operasional (Operational Audit).

\section{Audit Operasional}

Audit operasional atau pemeriksaan operasional disebut juga sebagai audit pemeriksaan manajemen. Beberapa ahli yang mendefinisikan audit operasional antara lain, Alvin. A. Arens, et, al. (2012) mengungkapkan bahwa "Operatonal audit is a review of any part of an organizations operating producers and methods for the purpose of evaluating efficiency and effectiveness". Tujuan audit operasional tidak hanya mendorong dilakukannya tindakan perbaikan tetapi jugauntuk menghindari kemungkinan terjadinya kekurangan atau kelemahan di masa yang akan dating pada aktivitas operasi perusahaan. Audit dikembangkan dan dilaksanakan karena audit member banyak manfaat bagi dunia bisnis. 


\section{Anggaran Biaya Operasi}

Anggaran biaya operasional adalah semua rencana pengeluaran yang berkaitan dengan distribusi dan penjualan produk perusahaan serta pengeluaran untuk menjalankan roda organisasi, Rudianto (2009).

\section{METODE}

\section{Pendekatan Penelitian}

Pendekatan yang digunakan dalam penelitian ini adalah pendekatan kualitatif. Objek Penelitian ini berlokasi lokasi penelitian akan dilaksanakan di Kota Makassar, Sulawesi Selatan Tepatnya di Jl. Hertasning, Blok B. Sedangkan waktu penelitian ini akan dilaksanakan selama 2 (dua) bulan. Adapun jenis data yang digunakan dalam penelitian ini adalah data kualitatif, sedangkan Sumber data yang diperoleh dalam penelitian ini adalah sumber sekunder.

\section{Metode Analisis Data}

Adapun metode analisis data yang digunakan untuk menguji adalah Analisa data dilakukan dengan menggunakan deskriptif kualitatif yaitu mengetahui peranan audit operasional dalam meningkatkan efektifitas pengendalian biaya operasi pada PT. PLN Wilayah Sulselbar.

\section{HASIL DAN PEMBAHASAN}

\section{Hasil Penelitian}

Dalam melakukan penelitian ini, penulis melakukan wawancara terhadap pegawai dilingkungan PT PLN (Persero) Wilayah Sulselrabar pada bagian Audit Operasional. Pembentukan komite audit pada PT PLN (Persero) Wilayah Sulselrabar berdasarkan Keputusan Menteri Badan Usaha Milik Negara No. KEP103/MBU/2002 tentang Pembentukan Komite Audit Bagi Badan Usaha Milik Negara. Pada pasal 5 telah dijelaskan syarat untuk dapat diangkat sebagai Komite Audit yaitu: memiliki integritas yang baik dan pengetahuan serta pengalaman kerja yang cukup; tidak memiliki kepentingan/keterkaitan pribadi yang dapat menimbulkan dampak negatif dan mampu berkomunikasi secara efektif. Oleh karena itu, fungsi audit harus independen dari aktivitas yang diaudit atau bebas dari semua ketergantungan termasuk dalam bidang keuangan. Dengan demikian, dibutuhkan integritas, objektivitas yang tinggi secara pribadi tidak mudah dipengaruhi oleh siapapun. Pernyataan tersebut didukung oleh pernyataan yang diungkapkan oleh Bapak Frans selaku audit internal di PT. PLN (Persero) Wilayah Sulselrabar.

"Proses yang sistematis dalam audit operasional menyangkut serangkaian langkah atau prosedur yang logis, terstruktur, dan terorganisasi. Aspek ini meliputi perencanaan yang baik, serta perolehan dan evaluasi secara objektif bukti yang berkaitan dengan aktivitas yang diaudit. Mengevaluasi operasi organisasi. Evaluasi atas operasi ini harus didasarkan pada beberapa kriteria yang ditetapkan dan disepakati”.

Perencanaan yang dilakukan oleh audit operasional terhadap laporan biaya operasi yaitu: menentukan tipe/kwalitas dan jumlah petugas yang diperlukan untuk melaksanakan pekerjaan; informasi apa yang harus dikumpulkan, bagaimana memperolehnya dan bagaimana mengevaluasi informasi tersebut; bukti apa dan berapa banyak yang harus diperoleh kesimpulan yang layak atas sasaran pemeriksaannya serta hasil apa yang diharapkan dalam rangka pembuatan laporan untuk pekerjaan yang akan dilaksanakannya. Pernyataan tersebut didukung oleh pernyataan yang diungkapkan oleh salah satu audit operasional di PT. PLN (Persero) Wilayah Sulselrabar.

"Audit operasional sebagai penyelesaian atas masalah efektifitas, karena pengujian terhadap efektifitas pengendalian biaya operasi oleh auditor intern merupakan bagian dari audit operasional tujuannya adalah membantu perusahaan menjalankan kegiatan usahanya supaya lebih efektif dan efisien".

Dalam ruang lingkup audit tercakup audit harus menilai cara-cara perlindungan harta kekayaan perusahaan dari berbagai mcam kecurangan, kecurian, kebakaran, penggelapan maupun kehilangan. Untuk melakukan hal tersebut maka audit operasional harus melakukan verifikasi atas keberadaan harta perusahaan dengan menggunakan prosedur audit yang sesuai.

Adapun prosedur audit operasional yaitu: survei pendahuluan yang dimaksudkan untuk mendapatkan gambaran bisnis perusahaan melalui tanya jawab dengan manajemen dan staf; penelaahan dan pengujian atas sistem pengendalian manajemen yang dimaksudkan untuk mengevaluasi dan menguji efektifitas dari pengendalian manajemen yang terdapat di 
perusahaan; pengujian terinci dimaksudkan untuk memeriksa terhadap transaksi apakah sesuai dengan kebijakan yang telah ditentukan dan langkah terkhir yaitu pengembangan laporan yaitu dengan menyusun laporan pemeriksaan bukan dengan opini mengenai kewajaran namun mengenai penyimpangan yang terjadi terhadap standar yang berlaku yang menimbulkan inefisiensi, inefektifitas serta ketidakhematan. Pernyataan tersebut diungkapkan oleh Bapak Deni berdasarkan hasil tahapan audit operasional pada PT. PLN Wilayah Sulselbar

"Langkah awal yang dilakukan oleh auditor internal adalah melakukan survey pendahuluan pada fungsi operasi agar memiliki pengetahuan yang cukup untuk mengetahui keadaan fungsi operasi yang akan diaudit.selain itu audit internal melakukan pemeriksaan terhadap hasil audit sebelumnya dan ketentuan atau kebijakn yang baru sebelumnya sampai akhir audit. Pada tahap ini audit internal dapat melakukan pengamatan sekilas atas fasilitas fisik, mencari data tertulis dan wawancara dengan manajemen. Dilanjutkan tahap audit mendalam tahap ini auditor melakukan studi dilapangan, dimana auditor melakukan tahapan langsung atas kegiatan operasi mulai dari penyusunan anggaran biaya operasi sampai dengan realisasi biaya operasi. Untuk mengetahui penyimpangan antara rencana dan realisasi biaya operasi dari hasil tersebut. Adanya analisis untuk mengetahui penyimpangan antara rencana dan realisasi biaya operasi dari hasil tersebut dapat disimpulkan bahwa berperannya audit operasional dalam meningkatkan efektivitas pengendalian biaya operasi dapat dilihat dari tercapainya rencana dan realisasi biaya operasi dan pertumbuhan perusahaan yang mengalami peningkatan sebesar $10 \%$.

\section{Pembahasan}

\section{Program Audit Operasional}

Dalam melakukan audit operasional pada PT. PLN (Persero) Wilayah Sulselrabar audit operasional memiliki program audit yang mengacu kepada Badan Pengawas Keuangan. Maksud dan program audit adalah agar kegiatan audit dapat erjalan dengan baik dan lebih terarah karena program audit yang baik penting dalam menunjang keberhasilan audit yang dikembangkan untuk membantu manajemen dalam mencapai tujuan dengan penegndalian yang aktif. Program audit pengendalian biaya operasional pada PT. PLN (Persero) Wilayah Sulselbar dibuat berdasarkan program kerja pemriksa tahuna satuan pengawasan yang didalamnya diatur pelaksanaan audit triwulan persemester atau pertahun.

\section{Pelaksanaan Audit Operasional atas Biaya Operasi}

Audit internal sebagai pelaksana audit operasonal pada PT. PLN (Persero) Wilayah Sulselrabar membantu pihak manajemen dalam usaha mencapai efektivitas pengendalian biaya operasi, selain itu kegiatan ini dilakukan untuk mendeteksi sedini mungkin berbagai kemungkian penyimpangan atau kelemahan yang mungkin ditemukan. Dalam melaksanakan audit operasional, Satuan Pengawasan Internal (SPI) melakukan semua fungsi audit operasional, yaitu:

a. Compliance berarti bahwa audit operasional telah melaksanakan aktivitas penilaian dan pemeriksaan terhadap pelaksanaan dan biaya operasi, kebijakan dan peraturan-peraturan yang telah ditetapkan mengenai biaya operasi. Kegiatan ini meliputi, mengadakan pengendalian terhadap pelaksanaan fungsi pengendalian biaya operasi dan menilai prosedur pengendalian biaya operasi yang telah ditetapkan oleh perusahaan.

b. Verification, berarti bahwa audit operasional telah melakukan penilaian dan pemeriksaan terhadap kebenaran datadaninformasi yang telah dihasilkan dari sistem akuntansi biaya operasi yang akurat, yaitu cepat dan dapat dipercaya catatan yang telah diverifikasi dapat ditentukan oleh audit internal tertentu apakah terdapat kelemahan dan kekurangan dalam prosedur pencatatan untuk diajukan saran-saran perbaikan. Kegiatan ini meliputi, memeriksa laporan biaya operasi disetiap unit atau objek yang akan diaudit, adapun dokumen yang diperiksa seperti bukti biaya operasi yang sesuai dengan tujuan masing-masing unit dan perusahaan.

c. Evaluation, berarti bahwa audit operasional telah melakukan aktivitas penilaian secara menyeluruh atas biaya operasi hal inimerupakan suatu cara untuk memperoleh kesimpulan yang menyeluruh dari kegiatan perusahaan yang berhubungan dengan aktivitas biaya operasi. Kegiatan ini meliputi, memeriksa laporan biaya operasi pada saat pelaksanaan audit dan 
membandingkan biaya operasi dan realisasi

biaya yang telah ditentukan oleh perusahaan.

\section{Efektivitas Pengendalian Biaya Operasi}

a. Rencana dan Realisasi Biaya Operasi
Rencana dan realisasi biaya operasi yang telah ditetapkan PT. PLN (Persero) Wilayah Sulselrabar selama dua tahun berturut-turut yaitu tahun 2015-2016 adalah sebagai berikut:

Tabel 1. Rencana dan Realisasi Biaya Operasi Tahun 2015

\begin{tabular}{|c|c|c|c|c|}
\hline \multirow{2}{*}{ Bulan } & \multicolumn{2}{|c|}{ Biaya Operasi } & \multicolumn{2}{|c|}{ Kontribusi } \\
\hline & Rencana & Realisasi & Selisish & Persentase (\%) \\
\hline Januari & 13.152 .763 & 12.106 .007 & -1.046 .756 & $95 \%$ \\
\hline February & 12.921 .609 & 15.426 .589 & 2.504 .980 & $106 \%$ \\
\hline Maret & 16.186 .306 & 13.931 .085 & -2.255 .221 & $94 \%$ \\
\hline April & 12.938 .202 & 13.446 .807 & 508.605 & $98 \%$ \\
\hline Mei & 15.016 .038 & 14.608 .460 & -407.578 & $93 \%$ \\
\hline Juni & 15.087 .564 & 16.047 .266 & 959.702 & $109 \%$ \\
\hline Juli & 16.778 .202 & 17.272 .602 & 494.400 & $108 \%$ \\
\hline Agustus & 15.900 .476 & 14.145 .268 & -1.755 .208 & $79 \%$ \\
\hline September & 15.787 .938 & 14.111 .491 & -1.676 .447 & $78 \%$ \\
\hline Oktober & 14.661 .439 & 16.696 .190 & 2.307 .751 & $112 \%$ \\
\hline November & 16.425 .246 & 15.967 .548 & -457.698 & $89 \%$ \\
\hline Desember & 16.429 .245 & 15.992 .369 & -1.729 .592 & $127 \%$ \\
\hline TOTAL & 181.285 .028 & 180.024 .682 & 1.260 .346 & $93 \%$ \\
\hline
\end{tabular}

Dari table 1 di atas bahwa penyimpangan yang terjadi sangat kecil, pada bulan Januari sebesar 95\%, bulan Maret sebesar 94\%, bulan Mei sebesar 93\%, bulan Agustus sebesar 79\%, bulan September sebesar $78 \%$ dan pada bulan November sebesar $89 \%$, ini disebabkan rendahnya biaya operasi, kendala di lapangan seperti gangguan sangat sedikit, sedangkan pada bulan Februari sebesar 106\%, bulan Juni sebesar 109\%, bulan Juli sebesar 108\%, bulan Oktober sebesar $112 \%$, dan pada bulan Desember sebesar $127 \%$ disebabkan

adanya kenaikan biaya operasi dikarenakan banyaknya gangguan lapangan seperti rusaknya jaringan intalasi, tetapi PT. PLN (Persero) Wilayah Sulselrabar sendiri tidak menetapkan suatu kriteria yang menentukan batas kewajaran dari penyimpangan yang ada.

Tabel 2. Rencana dan Realisasi Biaya Operasi Tahun 2016

\begin{tabular}{ccccc}
\hline \multirow{2}{*}{ BULAN } & \multicolumn{2}{c}{ BIAYA OPERASI } & \multicolumn{2}{c}{ KONTRIBUSI } \\
\cline { 2 - 5 } & Rencana & Realisasi & Selisish & Persentase (\%) \\
\hline Januari & 11.907 .567 & 11.158 .913 & -748.654 & $100 \%$ \\
\hline February & 11.997 .631 & 10.793 .012 & -1.204 .619 & $93 \%$ \\
\hline Maret & 15.606 .070 & 13.288 .045 & 2.318 .025 & $103 \%$ \\
\hline April & 12.202 .956 & 13.938 .260 & 1.375 .304 & $101 \%$ \\
\hline Mei & 15.591 .039 & 14.361 .669 & -1.229 .340 & $90 \%$ \\
\hline Juni & 12.043 .721 & 15.201 .387 & 2.957 .666 & $107 \%$ \\
\hline Juli & 17.854 .158 & 16.178 .105 & -1.676 .053 & $92 \%$ \\
\hline Agustus & 15.826 .846 & 14.145 .268 & -1.681 .578 & $80 \%$ \\
\hline September & 15.194 .750 & 14.172 .076 & -2.022 .674 & $85 \%$ \\
\hline Oktober & 19.695 .919 & 19.807 .011 & 11.092 & $92 \%$ \\
\hline November & 13.741 .711 & 15.725 .990 & 1.984 .279 & $113 \%$ \\
\hline Desember & 11.369 .707 & 11.105 .025 & 1.592 .157 & $89 \%$ \\
\hline TOTAL & 74.232 .075 & 169.874 .791 & 4.357 .284 & $83 \%$ \\
\hline
\end{tabular}

Dari tabel 2. di atas bahwa penyimpangan yang terjadi sangat kecil, pada bulan Agustus sebesar 80\%, bulan September sebesar 85\%, bulan Desember sebesar $89 \%$, ini disebabkan rendahnya biaya operasi, kendala di lapangan seperti gangguan sangat sedikit, sedangkan pada bulan Maret sebesar 103\%, bulan April sebesar $101 \%$, bulan November sebesar $113 \%$, ini disebabkan adanya kenaikan biaya operasi dikarenakan banyaknya gangguan lapangan seperti rusaknya jaringan intalasi, tetapi PT. PLN (Persero) Wilayah Sulselrabar sendiri tidak 
menetapkan suatu kriteria yang menentukan batas kewajaran dari penyimpangan yang ada.

Berdasarkan tabel 1 dan tabel 2 pertumbuhan PT. PLN Wilayah Sulselbar mengalami peningkatan dari tahun 2015 sampai 2016, kenaikan pertumbuhan PT. PLN Wilayah Sulselrabar ini dilihat dari rencana biaya operasi yaitu pada tahun 2015, dimana persentase rencana dan realisasi biaya operasi sebesar $93 \%$ dan pada tahun 2016 sebesar 83\%, sehingga kenaikan pertumbuhan perusahaan sebesar $10 \%$ (93\%-83\%). Pada PT. PLN (Persero) Wilayah Sulselbar tahap audit operasional dilaksanakan dalam beberapa tahap, yaitu:

a. ahap Audit Pendahuluan

Langkah awal yang dilakukan oleh auditor internal adalah melakukan survey pendahuluan pada fungsi operasi agar memiliki pengetahuan yang cukup untuk mengetahui keadaan fungsi operasi yang akan diaudit.selain itu audit internal melakukan pemeriksaan terhadap hasil audit sebelumnya dan ketentuan atau kebijakn yang baru sebelumnya sampai akhir audit. Pada tahap ini audit internal dapat melakukan pengamatan sekilas atas fasilitas fisik, mencari data tertulis dan wawancara dengan manajemen.

b. Tahap Audit Mendalam

Dalam tahap ini auditor melakukan studi dilapangan, dimana auditor melakukan tahapan langsung atas kegiatan operasi mulai dari penyusunan anggaran biaya operasi sampai dengan realisasi biaya operasi. Untuk mengetahui penyimpangan antara rencana dan realisasi biaya operasi dari hasil tersebut. Adanya analisis untuk mengetahui penyimpangan antara rencana dan realisasi biaya operasi dari hasil tersebut dapat disimpulkan bahwa berperannya audit operasional dalam meningkatkan efektivitas pengendalian biaya operasi dapat dilihat dari tercapainya rencana dan realisasi biaya operasi dan pertumbuhan perusahaan yang mengalami peningkatan sebesar $10 \%$.

\section{KESIMPULAN DAN SARAN}

\section{Kesimpulan}

Menurut hasil dan pembahasan yang dilakukan, maka penulis simpulkan bahwa audit internal PT PLN (Persero) Wilayah Sulselbar Audit Operasional berperan dalam meningkatkan efektivitas pengendalian biaya operasi, hal ini dapat dilihat dari: a. Pelaksanaan audit operasional di PT PLN (Persero) Wilayah Sulselrabar selalu mempertahankan indenpendensinya dimana auditor operasional diberi keleluasaan menyelesaikan tanggung jawabnya dengan jujur dan melaksanakan segala kemampuannya dalam mengaudit dan tetap mempertahankan sikap ojektifnya serta tercermin dari kedudukan unit audit yang terpisah dari bagian-bagian lain yang diperiksanya. Sehingga audit operasional dianggap mampu melaksanakan tugasnya dengan jujur dan obyektif kemudian mempengaruhi hasil akhir dari pemeriksaan. Dalam hal ini pengendalian biaya operasi berupa laporan hasil pemeriksaan yang dibuat oleh auditor cenderung obyektif dan juga agar audit operasional dapat mempertahankan pendapatnya dalam laporan audit mengenai penyimpangan yang mungkin telah, sedang atau mempunyai potensi terjadi yang dilakukan oleh oknum tertentu. Karena apabila audit operasional tidak mempunyai indenpendensi maka bisa saja penyimpangan terhadap penggunaan biaya operasi yang telah ditemukan atau diidentifikasi akan dihilangkan karena pengaruh dari oknum yang melakukan kesalahan dengan imbalan tertentu.

b. Auditor operasional dalam melakukan audit dalam hal ini efektivitas pengendalian biaya operasi yang mencakup pengujian, penilaian dan memberikan kontribusi peningkatan terhadap keandalan dan efektifitas sistem pengendalian perusahaan, governance serta kualitas kinerja pelaksanaan tugas yang sistematis, teratur dan menyeluruh dengan menggunakan metodemetode seperti yang tertuang pada Pedoman Pelaksanaan Tugas Staf Audit Internal. Hal ini mendukung pelaksanaan tugas mempengaruhi pelaksanaan kegiatan audit, sehingga pemeriksaan dapat dilaksanakan dengan optimal. Karena setiap informasi harus telah diuji dan dinilai informasi penggunaan biaya operasi hal ini disebabkan setiap informasi dapat menjadi informasi yang berguna.

c. Audit operasional berperan dalam meningkatkan efektivitas pengendalian biaya operasi dapat dilihat dari tercapainya rencana dan realisasi biaya operasi dan pertumbuhan perusahaan yang mengalami peningkatan sebesar $10 \%$. 


\section{Saran}

Peneliti menyadari bahwa dalam melakukan penelitian ini terdapat beberapa hal yang belum lengkap. Sehingga peneliti memberikan saran yaitu:

a. Karena keterbatsan waktu penelitian yang dilakukan hal ini menyebabkan kesulitan menemui responden disamping kesibukan yang dimiliki sehingga kemungkinan jawaban yang diberikan oleh responden adalah bias. Sehingga disarankan dalam melakukan penelitian mengenai audit operasional menyiapkan waktu yang cukup banyak untuk memperoleh hasil yang lebih optimal.

b. Dalam penelitian selanjutnya diharapkan mengungkapkan pertanyaanpertanyaan yang lebih banyak dan yang lebih spesifik lagi yang dituangkan dalam kuisioner maupun wawancara yang dilakukan dengan responden.

\section{REFERENSI}

Ahmad. E, dkk. 2012. Peranan Audit Operasional dalam Meningkatkan EfektivitasPenjualan pada PT. Delta Internusa Kota Palopo. Jurnal Equilibrium. Voil. 2 No. 12012.

Anam. F, dkk. 2013. Peranan Audit Operasional untuk Meningkatkan Kinerja Fungsi Pemasaran PT. Finance, Tbk. Jurnal Ilmu dan Riset Akuntansi. Vol. 2 No. 112013.

Arens, A.Alvin, Elder, J Randal, Beasley, S. Mark. 2006. Auditing and Assurance Service: An Integrated Approach. 11 edition, Upper Saddel River, New Jersey. Pearson Education International.

Alvin A. Arens, dkk. 2010. Auditing and Assurance Services An Integrated Approach 13t,h, edition. New jersey: Pearson

Aqieda. K. 2013. Peranan Audit Internal untuk Meningkatkan Efisiensi Produksi Listrik dan Penerimaan Kas PLTD Wilayah Distribusi Jawa Barat dan Banten pada PT. PLN (Persero). Jurnal Ilmiah Manajemen dan Akuntansi Fakultas Ekonomi. Vol. 22013.

Arvianita. R. 2015. Pengaruh Audit Operasional Dan Pengendalian Internal Terhadap Efektivitas Pelayanan Kesehatan Pada Rumah Sakit (Studi
Kasus Pada Rumah Sakit Umum Qeen Latifa Yogyakarta). Skripsi. Yogyakarta: Fakultas Ekonomi Universitas Negeri Yogyakarta.

Astasari, V. 2011. Peran Audit operasional Dalam Meningkatkan Efektivitas Kegiatan Perkreditan (Studi Kasus Pada Bank Nagari Cabang Utama Padang). Skripsi. Padang: Fakultas Ekonomi Universitas Andalas.

Bayangkara, IBK. 2008. Audit Manajemen: Prosedur dan Implementasi. Jakarta: SalembaEmpat.

Dewantara, A. 2006. Peranan Audit Operasional Dalam Efektivitas Penyelenggaraan Pendidikan Pada Sekolah Lapangan Pengendalian Hama Terpadu (Suatu Survei pada Dinas Perkebunan Provinsi Jawa Barat). Bandung

Ghozali, Imam. 2005. Aplikasi Analisis Multivariate dengan Program SPSS. Semarang: Badan Penerbit UNDIP.

Gultom. A. 2014. Peranan Audit Terhadap Peningkatan Mutu Pelayanan Kesehatan Rawat Inap Di Rumah Sakit Umum Makassar. Makassar: Fakultas Ekonomi Dan Bisnis Universitas Hasanuddin.

Guy, M dan C. Wayne Alderman, Alan J. Winters. 2006. Audit Operasional. Jakarta: Erlangga.

Hansen, Don. R, Mowen, Maryanne M. 2006. Management Accounting. Jakarta: Salemba Empat.

Henry, Simamora. 2010. Akuntansi Basis Pengambilan Keputusan Bisnis. Jakarta: Salemba Empat.

IBK Bayangkara. 2008. Audit Manajemen: Prosedur dan Implementasi. Jakarta: Salemba Empat.

Mulyadi. 2010. Auditing Jilid I, Cetakan ke Tujuh. Jakarta: Salemba Empat.

Mulyadi. 2009. Akuntansi Biaya. Edisi 5. Yogyakarta: Aditiya Media.

.. 2005. Auditing. Edisi 6. Jakata: Salemba Empat.

Nuraeni. 2014. Peranan Audit Operasional Dalam Meningkatkan Efektivitas Kegiatan Perkreditan (Studi Kasus pada PT. Bank Rakyat Indonesia Cabang Utama Pinrang). Skripsi. Makassar: Fakultas Ekonomi dan Bisnis Universitas Hasanuddin. 
Peraturan Bank Indonesia Nomor:1/6/PBI/1999 Tentang Penugasan Direktur Kepatuhan dan Penerapan Standar Pelaksanaan Fungsi Audit Intern Bank.

Panjaitan, P. 2014. Peranan Audit Operasional Dalam Menunjang Efektivitas Penjualan (Studi Kasus Pada PT. Victory Surabaya). Skripsi. Surabaya: Fakultas Ekonomi Universitas Wijaya Putra.

Rosdiyati. 2016. Audit Operasional atas Fungsi Produksi Perusahaan (Studi Kasus pada PT. JAYA BRIX Indonesia). Jurnal Penelitian Ekonomi dan Akuntansi. Vol. 1 No. 12016.

Saragih. Y. 2005. Peranan Audit Operasional Dalam Mendorong Efektivitas Pelayanan Kesehatan Unit Gawat Darurat (Studi Kasus pada Perjan Rumah Sakit Dr. Hasan Sadikni). Fakultas Ekonomi Universitas Widyatama.

Sukirno, Agoes. 2010. Auditing. Jakarta: Lembaga Penerbit Fakultas Ekonomi Universitas Indonesia.

Sugiyono. 2008. Metode Penelitian Administrasi. Bandung: Alfabeta.

Widjayanto, Nugroho. 2004. Pemeriksaan Operasional Perusahaan. Jakarta: FEUI. 